\title{
Surgical Management of Traumatic Interhemispheric Subdural Hematoma
}

\section{Travmatik Interhemisferik Subdural Hematomun Cerrahi Tedavisi}

\author{
Yuhai $W_{A N G}{ }^{1}$, Chunli WANG ${ }^{1}$, Sang CAI ${ }^{1}$, Jirong DONG ${ }^{1}$, Likun YANG ${ }^{1}$, Lei CHEN ${ }^{1}$, Andrew I. R. MAAS \\ 1101 Hospital of Chinese People's Liberation Army, Department of Neurosurgery, Wu Xi, Jiang Su, China \\ ${ }^{2}$ Antwerp University Hospital, Edegem, Belgium and University of Antwerp, Department of Neurosurgery, Antwerp, Belgium
}

Corresponding Author: Wang YUHAI / E-mail: yuhaitwang@163.com

\begin{abstract}
AIM: To review our experience in the surgical treatment of TISH, and to analyze prognostic factors.

MATERIAL and METHODS: Clinical and imaging data, surgical modalities, and outcomes of 21 patients with TISH who were treated with microsurgery were analyzed retrospectively. Prognostic factors for outcome were analyzed by univariate analysis.

RESULTS: Long-term follow up with outcome assessment according to the Glasgow Outcome Scale (GOS) showed good recovery in 16 cases, moderate disability in two cases, severe disability in one case, and death in two cases. During surgery the origin of bleeding could be identified in all 21 cases. A rupture of the distal anterior cerebral artery or veins in the interhemispheric fissure was seen more frequently in patients with whole interhemispheric fissure hematoma, while hemorrhage from brain tissue laceration was seen more frequently in patients with more localized hematomas. The outcome in patients with an identified rupture of a vessel was better than in those with cortical laceration. Preoperative GCS score and thickness of the interhemispheric hematoma were correlated with outcome $(\mathrm{P}=0.001$ and $\mathrm{P}=0.004$, respectively). CONCLUSION: Outcome after surgical treatment for TISH can be good, and careful surgical planning and microsurgical techniques to preserve venous drainage are essential.
\end{abstract}

KEYWORDS: Traumatic interhemispheric subdural hematoma, Surgery, Outcome, Prognosis, Traumatic brain injury

ÖZ

AMAÇ: Travmatik interhemisferik subdural hematom cerrahi tedavisi konusunda deneyimimizi gözden geçirmek ve prognostik faktörleri analiz etmek.

YÖNTEM ve GEREÇLER: Mikrocerrahi ile tedavi edilen 21 travmatik interhemisferik subdural hematom hastasında klinik ve görüntüleme verileri, cerrahi modaliteler ve sonuçlar retrospektif olarak analiz edildi. Sonuç için prognostik faktörler tek faktörlü analiz (univariate) ile analiz edildi.

BULGULAR: Glasgow Sonuç Ölçeği (GOS) uyarınca sonuç değerlendirmesiyle uzun dönemli takip 16 olguda iyi bir iyileşme, iki olguda orta derecede malüliyet, bir olguda şiddetli malüliyet ve iki olguda ölüm gösterdi. Cerrahi sırasında kanamanın kaynağı 21 olgunun tümünde tanımlanabildi. İnterhemisferik fissürde distal anterior serebral arter veya venlerin rüptürü tam interhemisferik fissür hematomu olan hastalarda daha sıkken, beyin dokusu laserasyonundan hemoraji daha lokalize hematomları olan hastalarda daha sıktı. Tanımlanmış damar rüptürü olan hastalarda sonuç kortikal laserasyonu olanlardan daha iyiydi. Preoperatif Glasgow Koma Ölçeği skoru ve interhemisferik hematom kalınlığı sonuçla ilişkiliydi (Sırasıyla $\mathrm{P}=0,001$ ve $\mathrm{P}=0,004$,).

SONUÇ: Travmatik interhemisferik subdural hematom için cerrahi tedavi sonrasında sonuç iyi olabilir ve venöz drenajı korumak için dikkatli cerrahi planlama ve mikrocerrahi teknikler çok önemlidir.

ANAHTAR SÖZCÜKLER: Travmatik interhemisferik subdural hematom, Cerrahi, Sonuç, Prognoz, Travmatik beyin yaralanması

\section{INTRODUCTION}

Traumatic interhemispheric subdural hematoma (TISH) is a rare clinical event in cases of traumatic brain injury (TBI), and the literature is restricted to a small number of clinical cases or individual case reports (1-2,4,5-9). One of the largest series was reported by Takeuchi et al (9), who described the results of conservative treatment in 35 cases with TISH and reported a mortality rate of $29 \%$. Controversy exists about the management of TISH, and reports on outcomes after TISH show mortality rates of $24 \%$ to $35 \%(2,6,9)$. To our knowledge there are no large series reporting specifically on the results of the surgical treatment of TISH. We therefore aimed to review our experience in the surgical management of TISH by parasagittal craniotomy, and to analyze prognostic factors.

\section{MATERIAL and METHODS}

Out of 6,840 cases of TBI treated in our department from January 2000 to December 2010, we identified 21 (0.3\%) cases with TISH that were treated surgically. Clinical data, imaging data, surgical modalities, and therapeutic outcomes of these 21 cases were reviewed retrospectively. The need for informed consent was waived by our institutional review board as this 
was an observational retrospective study without any study intervention.

All 21 patients underwent head computed tomography (CT) before surgery, including CT angiography (CTA) in 6

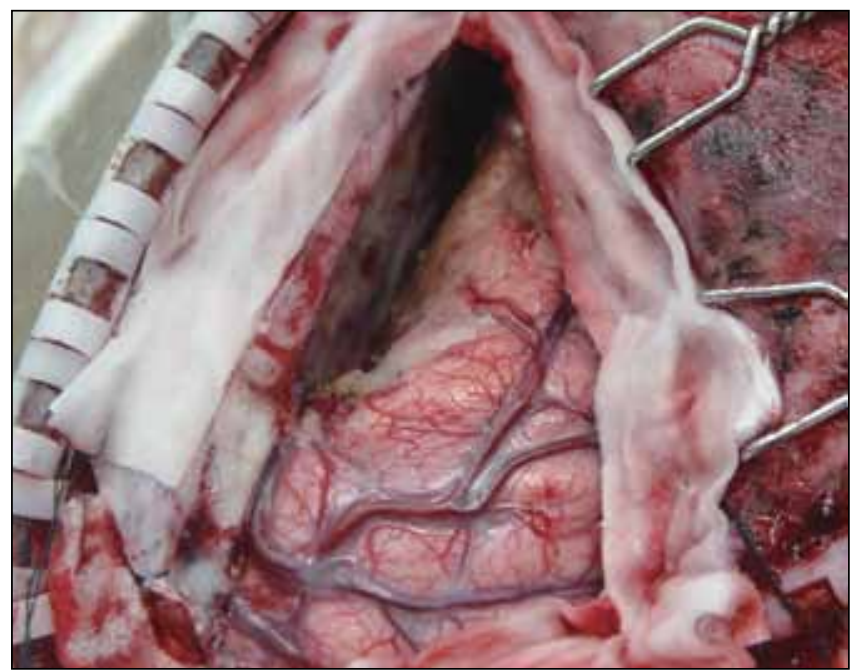

Figure 1: Intra-operative removal of the hematoma through the anterior space of the frontoposterior vein. The vein was well preserved after surgery.

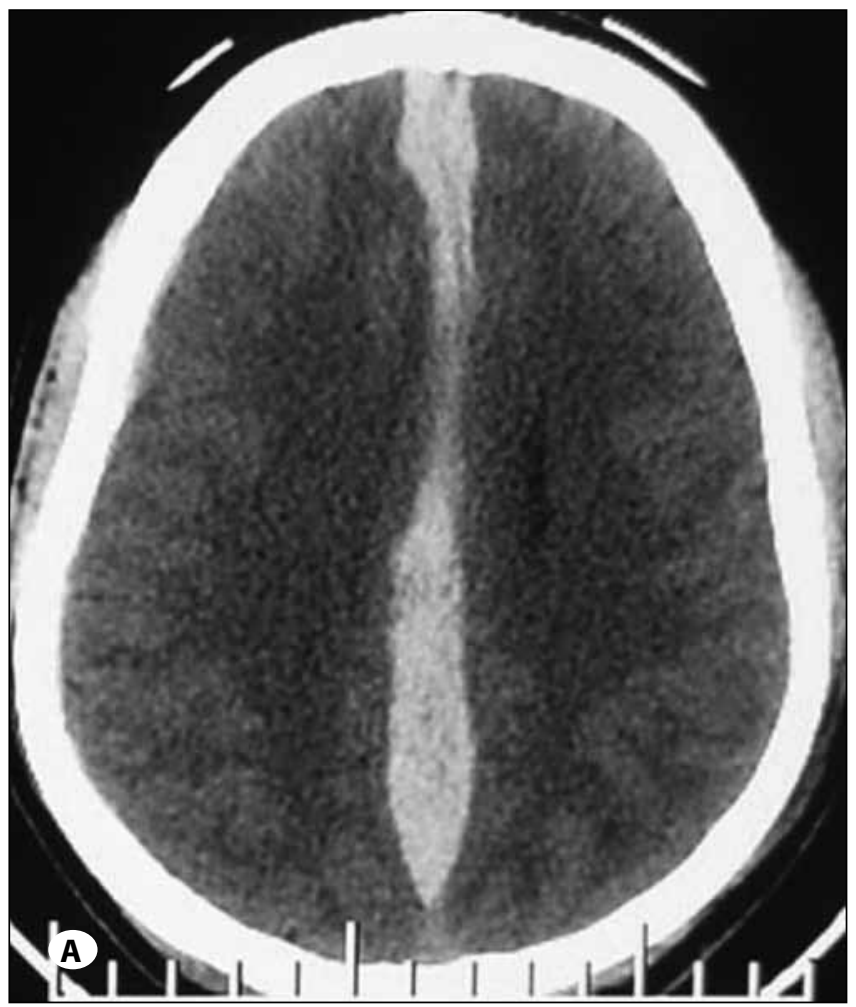

patients. Using the central sulcus as the demarcation, the interhemispheric fissure was divided into anterior and the posterior portions, and the location of the hematoma classified according to this differentiation. When the indication for surgery was determined, cranial flaps were planned along the sagittal sinus in all patients. In patients with hematomas in the anterior part of the interhemispheric fissure or in the entire interhemispheric fissure, surgery was performed through the space between the middle frontal vein and the frontoposterior vein, or between the frontoposterior vein and the anterior vein of the central sulcus (Figure 1). In patients with unilateral hematomas, the hematoma was removed by ipsilateral craniotomy, while in patients with bilateral hematomas only the larger hematoma, or the hematoma causing significant dysfunction was removed (Figure 2A, B). Hematomas in the interhemispheric fissure were removed gradually by adjusting the position of the head and the angle of the microscope. Special care was given not to retract or manipulate the brain tissue, and to protect the distal segment and branches of the anterior cerebral artery (ACA), the bridging veins beside the superior sagittal sinus, and the median longitudinal veins during the process of hematoma removal. Whether or not bone flaps were replaced after removing the hematoma depended on the preoperative Glasgow Coma Scale (GCS) score and intracranial edema of the patient. In 4 patients bone flaps were not replaced.

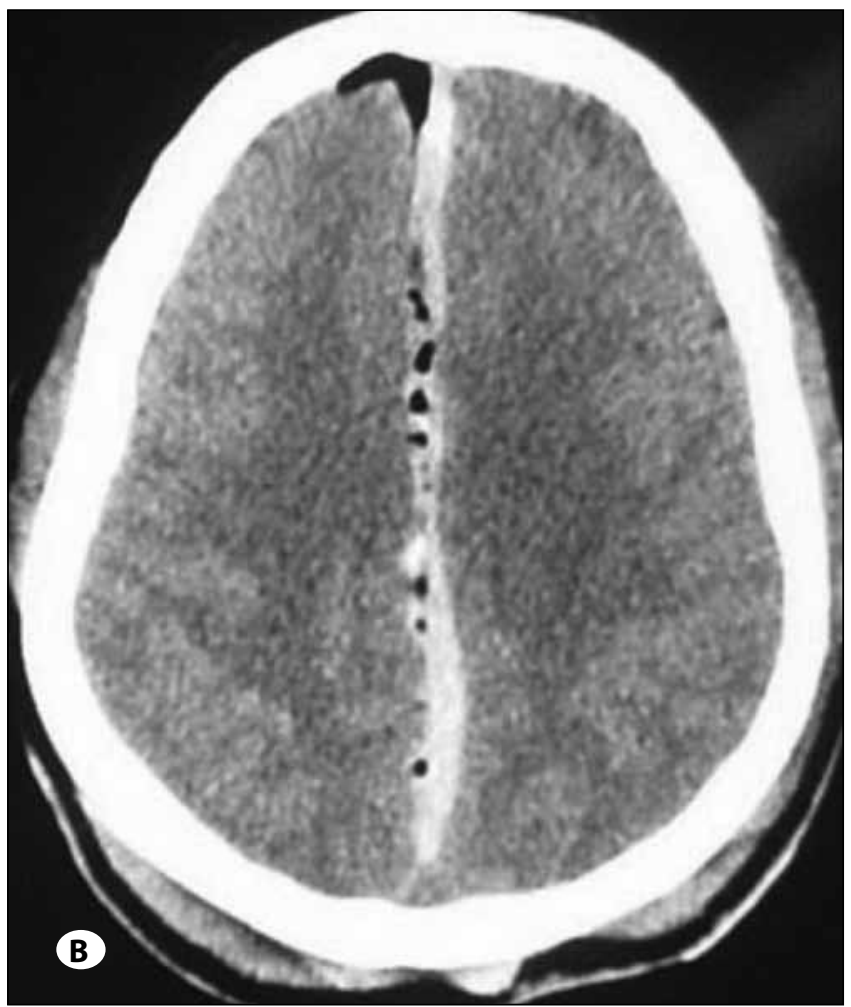

Figure 2: Bilateral traumatic interhemispheric subdural hematoma before and after surgery. The 54-year female patient was injured while riding a bicycle. A) Head computed tomography 38 hours after injury showed bilateral interhemispheric subdural hematoma. Pre-operative Glasgow Coma Scale score was 11, with dysphasia. Muscle strength of the left lower extremity was grade I. B) The main intra-operative intent was to remove the right hematoma. As the left hematoma was small, it was not surgically removed. The patient's language ability and muscle strength of the right lower extremity restored to a normal level 3 months after injury. 
Outcomes were evaluated after at least 6 months (range 6 months to 9 years) according to the Glasgow Outcome Scale (GOS). Outcome was differentiated into favorable outcome (good recovery and moderate disability) and unfavorable outcome (severe disability, vegetative survival and death).

\section{Statistical Analysis}

Age, GCS, mean hematoma volume, hematoma thickness, and other quantitative parameters were statistically analyzed and expressed as mean \pm standard deviation (SD). The correlation of clinical and radiological parameters with outcome was analyzed by Chi-square test and t test. Statistical assessments were considered significant when $\mathrm{P}<0.05$. Statistical analyses were performed using SPSS 16.0 statistics software (SPSS Inc., Chicago, IL, USA).

\section{RESULTS}

\section{Patient Characteristics}

Characteristics of the study population are summarized in Table I. The causes of injury included traffic accidents in 14 cases, fall from height in 4 cases, and fall at ground level in 3 cases. Three patients had a confirmed history of alcohol consumption, one patient had a long history of using anticoagulants, and one patient had coagulation dysfunction as indicated by a low preoperative platelet count of $6.5 \times 10^{9} / \mathrm{L}$. The preoperative GCS score was 3 to 8 in two cases, 9 to 12 in six cases, and 13 to 15 in 13 cases. Unilateral lower extremity dysfunction was found in 14 cases, bilateral lower extremity dysfunction in three cases, and seizures in five cases.

CT examination showed a typical imaging presentation of a hematoma in the midline interhemispheric fissure area, adjacent to the cerebral falx, and often protruding to one side (Figure 3). Bilateral hematomas were found in four cases (Figure 4). Although only performed in six cases, CTA was helpful in identifying mass effects on the course of the pericallosal artery. An example is shown in Figure 5, demonstrating that the distal segment of the anterior cerebral artery was pushed laterally by the hematoma. Sagittal reconstruction of the CT data provided good insight into the anteroposterior extent of the hematoma, and was thus found to be essential for planning surgery. The presence of a TISH was discovered on the initial CT scan in 11 cases, and by CT re-examination in 10 cases.

The hematoma was located in the anterior part of the interhemispheric fissure in five cases, in the posterior part in three cases, and in the entire interhemispheric fissure in 13 cases. The blood volume of the hematomas ranged from 40 $\mathrm{ml}$ to $70 \mathrm{ml}$. Isolated TISH was found in nine cases, and TISH was complicated with subdural hematoma in six cases, skull fracture in four cases (occipital fracture in two cases and frontal bone fracture in two cases), cerebral laceration in six cases, and subarachnoid hemorrhage in seven cases.

\section{Surgical Treatment and Outcomes}

Craniotomy was performed as an emergency procedure
Table I: Patient Characteristics

\begin{tabular}{|l|r|}
\hline Age (y) & $53 \pm 6.5$ \\
\hline Gender: male & $15(71)$ \\
\hline Glasgow Coma Scale score & \\
$\quad \leq 8$ & $2(10)$ \\
\hline $9-12$ & $6(28)$ \\
\hline $13-15$ & $13(62)$ \\
\hline Pupillary abnormalities & $1(5)$ \\
\hline CT Findings & $17(81)$ \\
$\quad$ Unilateral & $4(19)$ \\
\hline$\quad$ Bilateral & $5(24)$ \\
\hline Interhemispheric fissure & $3(14)$ \\
\hline$\quad$ Anterior & $13(62)$ \\
\hline$\quad$ Posterior & $6(28)$ \\
\hline Anterior + posterior & $7(33)$ \\
\hline Associated ASDH & $7(33)$ \\
\hline Traumatic subarachnoid hemorrhage & $14(67)$ \\
\hline Surgery & $3(14)$ \\
\hline$\quad$ Immediate & $18(86)$ \\
\hline Delayed & \\
\hline Outcome & Unfavorable \\
\hline Favorable & \\
\hline
\end{tabular}

Data are presented as mean \pm standard deviation or number (percentage). ASDH, acute subdural hematoma.

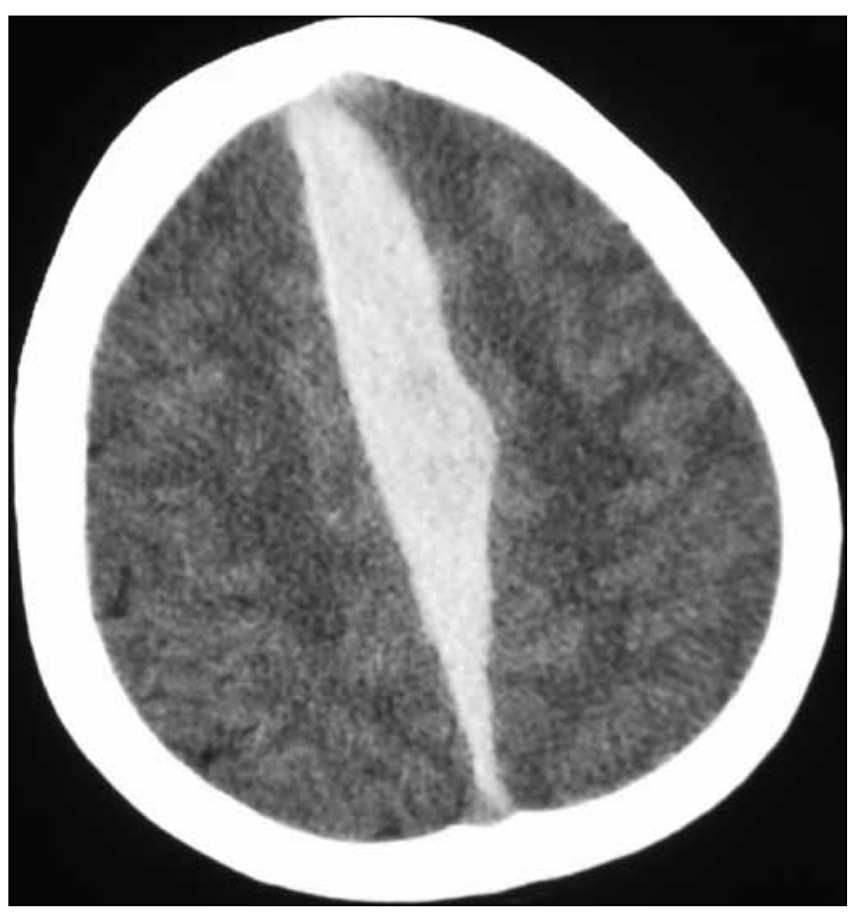

Figure 3: Left interhemispheric subdural hematoma. The hematoma protrudes to the left; the right side is limited by the cerebral falx, with a well-defined margin. 


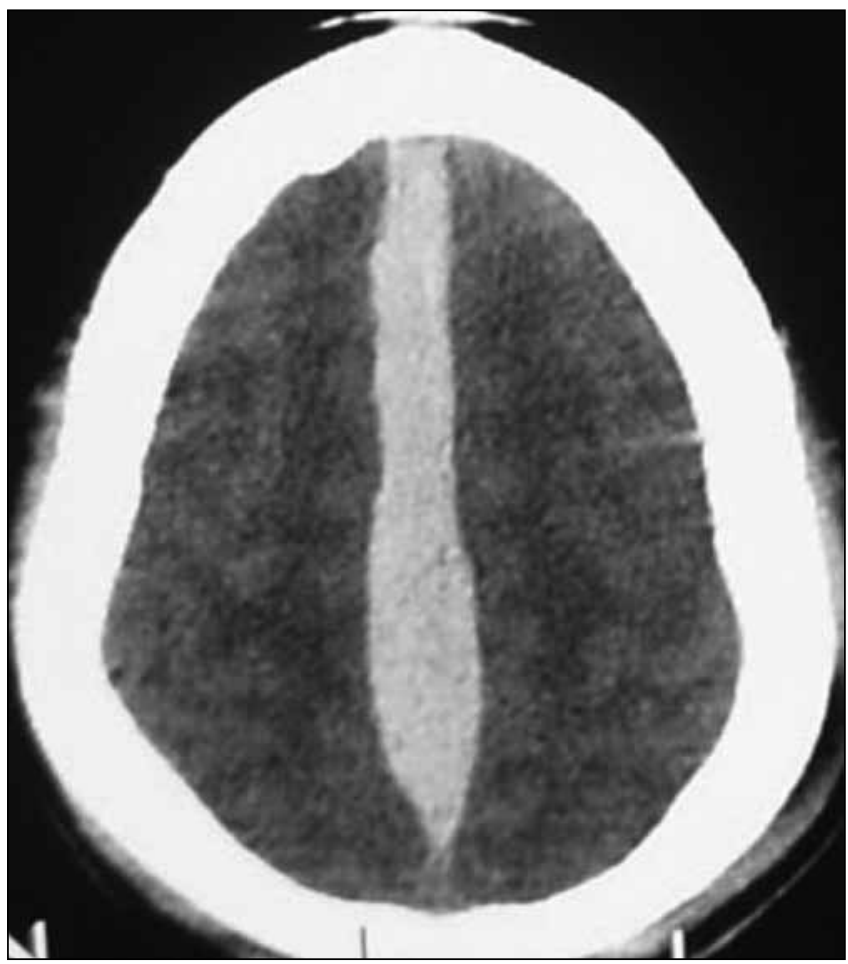

Figure 4: Bilateral interhemispheric subdural hematoma. The hematoma protrudes to both sides, with irregular margins on both sides.

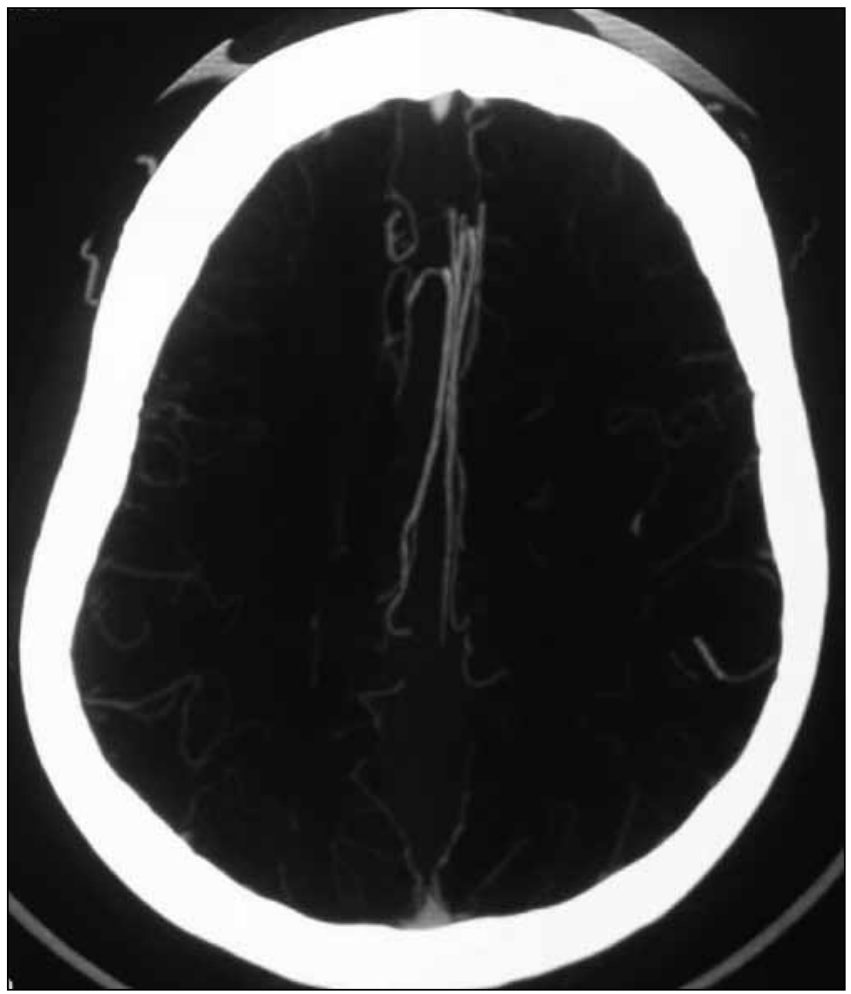

Figure 5: Computed tomography angiography showed the hematoma displacing the distal anterior cerebral artery to the left, with an avascular area in the center.
Table Il: Origin of Bleeding

\begin{tabular}{|l|r|}
\hline Branches of pericallosal artery & 10 \\
\hline Vein in the interhemispheric fissure & 12 \\
\hline Brain laceration in the interhemispheric fissure & 6 \\
\hline Lesion of parasagittal bridging vein & 1 \\
\hline
\end{tabular}

In 7 patients both a lesion of the pericallosal artery and veins in the interhemispheric fissure were found at surgery; in one patient a cortical laceration was associated with rupture of a parasagittal bridging vein.

within 8 hours after injury in seven of the 21 TISH patients. Nine patients were initially treated conservatively, but later underwent craniotomy because of progression of neurological deficits or deterioration of consciousness. In five patients the indication for surgery was increased intracranial pressure $(>30 \mathrm{~mm} \mathrm{Hg}$ ) occurring within 4 days after injury.

At surgery the origin of the TISH hemorrhage could be clearly identified in all 21 cases (Table II). It is noteworthy that rupture of the parasagittal bridging veins was not the main cause of the TISH hemorrhage, occurring in only one patient in our series. We consider it likely that in this patient the bridging veins may have ruptured due to enlargement of the hematoma, with subsequent stretching of the veins.

Outcomes were good recovery in 16 cases, moderate disability in two cases, severe disability in one case, and death in two patients. Early death occurred in one patient whose preoperative GCS score was 4 with a unilateral dilated pupil, and multiple systemic injuries. The patient received emergent surgery, but died later of brain stem failure. Delayed death after remaining in a vegetative state for 18 months occurred in a second patient who initially had a GCS score of 11 . Craniotomy was performed later because of a decrease of the GCS score to 6 . Intra-operative findings revealed diffuse cerebral swelling, and postoperative $C T$ showed infarction in the area supplied by the ACA.

\section{Prognostic Analysis}

Univariate analysis of risk factors for unfavorable outcome showed that low GCS score and greater thickness of the interhemispheric hematoma were correlated with poorer outcomes ( $\mathrm{P}=0.001$ and $\mathrm{P}=0.004$, respectively) (Table III). The lower the GCS score, the poorer the prognosis.

An association was also noted between the origin of the hematoma and outcome. Unfavorable outcome occurred in three of the six patients (50\%) in whom hemorrhage was due to brain laceration along the interhemispheric fissure. Conversely, outcome was favorable in all 15 patients in whom the hematoma was caused by laceration of branches of the pericallosal artery or of the veins in the interhemispheric fissure.

\section{DISCUSSION}

Our experience in the treatment of patients with TISH shows that careful surgical planning combined with the use of 
Table III: Univariate Analysis of Prognostic Factors Related to Outcome in Patients with Traumatic Interhemispheric Subdural Haematomas

\begin{tabular}{|c|c|c|c|c|}
\hline Variable & $\begin{array}{l}\text { All patients } \\
(n=21)\end{array}$ & $\begin{array}{l}\text { Favorable outcome } \\
\qquad(n=18)\end{array}$ & $\begin{array}{l}\text { Poor outcome } \\
\qquad(n=3)\end{array}$ & P value \\
\hline $\operatorname{Sex}(M / F)$ & $15 / 6$ & $13 / 5$ & $2 / 1$ & 0.844 \\
\hline Age $(y)$ & $52.9 \pm 6.5$ & $52.3 \pm 5.2$ & $56.7 \pm 6.5$ & 0.287 \\
\hline Mechanism of injury (fall/traffic accident) & $7 / 14$ & $5 / 13$ & $2 / 1$ & 0.186 \\
\hline GCS score & $12.3 \pm 3.1$ & $13.3 \pm 1.9$ & $6.3 \pm 2.5$ & 0.001 \\
\hline Falx syndrome & 17 & 15 & 2 & 0.496 \\
\hline Time between injury and operation (h) & $34 \pm 2.3$ & $35.8 \pm 2.2$ & $23 \pm 3.0$ & 0.38 \\
\hline Mean hematoma volume $(\mathrm{ml})$ & $53.8 \pm 7.1$ & $53.9 \pm 7.4$ & $53.3 \pm 5.8$ & 0.903 \\
\hline Mean hematoma thickness $(\mathrm{mm})^{*}$ & $13.0 \pm 1.6$ & $12.6 \pm 1.4$ & $15.3 \pm 0.6$ & 0.004 \\
\hline
\end{tabular}

microsurgical techniques to preserve draining veins leads to good outcomes. Nevertheless, there are controversies regarding the management of TISH, particularly concerning indications for surgery. Bartels et al. (1) reported that there was no significant difference in outcomes between conservative therapy and surgical therapy for the treatment of TISH, while Psaltis et al. (7) reported that the mortality rate of surgical treatment was higher than that of conservative treatment. Takeuchi et al. (9) reported 35 cases of TISH treated conservatively, in whom the mortality rate was $29 \%$. The authors believed that the surgical outcome should be good in patients with simple TISH in the interhemispheric fissure because it does not cause severe damage to the brain tissue. Our findings are consistent with this opinion as outcomes were favorable in all cases with the bleeding origin identified as branches of the pericallosal artery or interhemispheric veins, while it was unfavorable in $50 \%$ of patients with cortical lacerations. One patient in our series initially remained vegetative for 18 months after surgery before dying. Pozzati et al. (8) reported two patients who deteriorated suddenly during conservative treatment, and intra-operative findings confirmed the rupture of the superior parasagittal bridging vein. Both patients died after surgery. Our experience in the surgical management of TISH showed that secondary deterioration is common, and subsequent surgery was required in 14 patients (67\%) because of progressive neurologic deterioration or increased intracranial pressure. From the perspective that severe disability may result from neurologic deterioration, other authors have advocated aggressive surgical therapy in patients with TISH with signs of deterioration (1-2,5-6,10). In our opinion, treatment of TISH should be individualized. For patients with a small hematoma, or in whom clinical symptoms or signs are not apparent, conservative therapy is preferable. The favorable results and low mortality (10\%) obtained with surgical treatment in our series, however, indicate that a more liberal approach to surgical indications may be warranted.
Many studies (1-2,5-6,10) have advocated that exacerbation of the clinical symptoms and signs should be the indication for surgery in patients with TISH. We suggest that surgery should be considered if: 1) progression of the clinical symptoms and signs, especially exacerbation of lower extremity weakness, occurs; 2) paralysis of both lower extremities is present; 3 ) there is persistent increased intracranial pressure (> $30 \mathrm{~mm}$ $\mathrm{Hg}$ ); and 4) the hematoma volume is $>40 \mathrm{ml}$ and/or the hematoma thickness is $>15 \mathrm{~mm}$. The reasons that the surgical outcomes were better in our study than in others $(3,7)$ is likely due to the selection of patients, timing of surgery, and surgical techniques.

We consider meticulous planning and execution of surgery important, and suggest a number of recommendations for improving outcomes. 1) Determine which side of the longitudinal fissure the hematoma is on: TISH is usually on the contralateral side of the paralyzed side of the body; when the hematoma is near the cerebral falx the flax is usually flat and smooth, and pushes the brain tissue laterally; and the side of subarachnoid hemorrhage usually corresponds to the side of TISH. 2) On CTA, blood vessels are often displaced laterally by the TISH. 3) In cases of bilateral TISH, craniotomy is usually performed on the side of a larger hematoma. 4) The cranial flap should be performed where the hematoma is the thickest with the fewest bridging veins. 5) Determination of the bleeding source: in all cases in this series the source of bleeding was identified. In the process of removing the hematoma in the longitudinal fissure, bleeding vessels should be identified and meticulous hemostasis performed to prevent re-bleeding. The thickest area of the hematoma is often the point of bleeding, and special attention should be given to the reading of axial and sagittal CT images. 6) Hematoma removal is best performed with the aid of a microscope, and special attention should be given to avoid excessive manipulation or retraction of the brain tissue in the median interhemispheric fissure, and to protection of the veins and perforating arteries in the interhemispheric fissure. 7) Prevention of vasospasm should be considered, and after removing the hematoma the 
longitudinal fissure cistern should be thoroughly irrigated to remove all blood clots. Irrigation with a papaverine solution may also be considered. 8) Prophylaxis for the prevention of seizures should be considered. Seizures occurred in five of 21 patients in our series, and this high incidence justifies the administration of anti-seizure medications.

As shown in Table III, the GCS score was closely correlated with the outcome $(P=0.001)$, which is consistent with other reports (9). In the three patients with poor outcomes, including one patient who was converted from conservative treatment to surgical treatment in the early period of the study, the preoperative GCS score was only $6.3 \pm 2.5$. We suggest that the prognosis would be improved significantly if surgical intervention is initiated before the patient's condition deteriorates. Outcome was also closely correlated with the thickness of the interhemispheric fissure hematoma $(P=0.004)$. The mean thickness of hematoma was $15.3 \pm 0.6$ $\mathrm{mm}$ in patients with a poor prognosis in our series. The poorer outcome in patients with a thicker hematoma may not only have resulted from an increased mass effect and local toxicity of hemoglobin degradation products on the cerebral cortex, but may also have been the result of stretching of the parasagittal bridging vein due to the increased mass effect affecting the drainage of blood through the superficial cerebral veins.

We also found that outcome was related to the origin of the hematoma. Poorer outcomes were observed in patients in whom the hematoma was due to cortical lacerations. Identification of the source of bleeding is therefore also relevant from a prognostic perspective. In a review of the literature before 1995, Borzone et al. (2) found that most studies did not report a confirmed source of bleeding. The frequent occurrence of an arterial or venous origin of a TISH suggests that TISH is a different condition from an acute subdural hematoma over the convexity where the coexistence of cortical contusion is much more frequent.

\section{Limitations}

Several limitations of our study should be acknowledged. First, we have only reviewed our experience in the surgical management of TISH. Consequently, no inferences can be made concerning overall treatment results. Second, the number of patients included in our series is small. This underlines that the occurrence of TISH as post traumatic hematoma is a rare event. The low number of patients, and in particular the very low number of patients with an unfavorable outcome, confounds the possibility of an extensive prognostic analysis. Thus, results presented concerning prognostic parameters should be considered no more than exploratory by nature.

\section{CONCLUSIONS}

We conclude that TISH is a rare clinical event following TBI. From a pathophysiologic perspective, it has different characteristics from an acute subdural hematoma over the convexity. Our results demonstrate that outcomes after surgical management for TISH are generally good. We consider careful surgical planning and the use of microsurgical techniques to preserve venous drainage essential elements for obtaining good results.

\section{REFERENCES}

1. Bartels RH,Verhagen WI,Prick MJ, Dalman JE:Interhemispheric subdural hematoma in adults: Case report and review of the literature. Neurosurgery 36:1210-1214,1995

2. Borzone $M$, Altomonte $M$, Baldini $M$, Rivano C: Typical interhemispheric subdural haematomas and falx syndrome: Four cases and a review of the literature. Zentralbl-Neurochir 56:51-60,1995

3. Clein LJ, Bolton CF: Interhemispheric subdural hematoma: A case report. J Neurol Neurosurg Psychiat 32:389-392,1969

4. Elsner H, Rigamonti D, Corradino G, Schlegel R Jr, Joslyn J: Delayed traumatic intracerebral hematomas: "SpatApoplexie". Report of two cases. J Neurosurg 72:813-815,1990

5. Gartman JJ Jr, Atstupenas EA, Vollmer DG, Powers SK: Traumatic laceration of pericallosal artery resulting in interhemispheric subdural hematoma: A case report. J Emerg Med 7:603-610,1989

6. Houtteville JP, Toumi K, Theron J, Derlon JM, Benazza A, Hubert P: Interhemispheric subdural haematomas: Seven cases and review of the literature. Brit J Neurosurg 2: 357-367,1988

7. Psaltis $A$, Lath $R$, McDonald $M$ : Acute interhemispheric subdural haematoma. J Clin Neurosci 11:546-548,2004

8. Pozzati E, Gaist G, Vinci A, Poppi M:Traumatic interhemispheric subdural hematoma. J Trauma22:241-243,1982

9. Takeuchi S, Takasato $Y$, Masaoka H, Hayakawa T, Yatsushige $\mathrm{H}$, Sugawara T: Traumatic interhemispheric subdural haematoma: Study of 35 cases. J Clin Neurosci 17:1527-1529,2010

10. Toffol GJ, Biller J, Adams HP Jr: Interhemispheric subdural hematoma. J Emerg Med 4:103-107,1986 